\title{
A ALMA DE UMA CIDADE: NATUREZA E CULTURA NA FRANÇA EQUINOCIAL NA VISÃO DE CLAUDE D’ABBEVILLE
}

\section{The soul of a city: nature and culture on the Equinoctial France in the vision of Claude d'Abbeville}

\author{
Amilcar Torrão Filho* \\ Daniel Rincon Caires**
}

\begin{abstract}
RESUMO
Este artigo tem como finalidade observar as mudanças que ocorreram nas relações entre os seres humanos e o meio ambiente na região da Ilha do Maranhão a partir do estabelecimento da França Equinocial, no início do século XVII, usando como referência principal o relato escrito pelo capuchinho Claude d'Abbeville, produzido no momento em que a cultura dos índios Tupinambá, antigos senhores da região, tinha contato com os valores europeus, num processo que se desdobra na adoção de novas práticas e posicionamentos frente ao mundo natural.
\end{abstract}

Palavras-chave: França Equinocial; história ambiental; contatos culturais; viajantes.

\begin{abstract}
This article is an effort to observe the changes that occurred in the relations between human being and natural environment in the Island of Maranhão area, from the moment of the establishment of Equinoctial France, in the early $17^{\text {th }}$ century, using as main reference to that the account of the capuchin Claude d'Abbeville, written in the very moment that the Tupinambá culture, traditional owners of that area, begun contacting with the European values, in a process that ensues in the adoption of new practices and positioning about the natural world.

Key-words: Equinoctial France; environmental history; cultural contacts; travelers.

* Pontifícia Universidade Católica de São Paulo.

** Historiador do Instituto Brasileiro de Museus - IBRAM, Museu Casa Histórica de Alcân-
\end{abstract} tara, Maranhão. 


\section{Considerações iniciais}

A chamada França Equinocial, empreendimento de colonização que ocorreu no Maranhão a partir de 1612, marcou o momento em que os europeus definitivamente estabeleceram-se na região, instalando uma sede administrativa, estruturas militares e religiosas e os primeiros núcleos habitacionais à moda do Velho Mundo. Até então, os contatos se restringiam a iniciativas comerciais adventícias e fragmentadas, de caráter informal, num modelo de relação que permitia certa continuidade da cultura nativa que, apesar de sensivelmente modificada pelos costumes exógenos, ainda mantinha sua estrutura básica de funcionamento. Essa situação se modificou bastante com a chegada do empreendimento colonial francês. $O$ fato de haver entre os recém-chegados um grupo de quatro religiosos já aponta a natureza das novas relações pretendidas a partir daí. A cultura Tupinambá, até então tolerada - e mesmo emulada -, passaria a ser combatida e censurada, para que no lugar se implantasse o sistema de valores dos europeus. A narrativa de Claude d'Abbeville é a história do contato entre essas duas culturas, das tensões e negociações entre elas, do estranhamento mútuo, da incompreensão. Mas também revela a adoção de uma atitude cautelosa por parte dos franceses, de certo respeito inspirado pelo temor e pela constatação da fragilidade de sua posição. Após Guaxenduba, com a retomada portuguesa da área, esse cenário se modificaria de maneira brutal e repentina, e o que era respeito temeroso se tornaria guerra aberta de extermínio.

Este artigo busca detectar as implicações dessas mudanças no trato humano com a natureza. Europeus e Tupinambás tinham formas bastante diferentes de se posicionarem frente ao mundo natural; os índios do Maranhão, apesar de não possuírem valores específicos voltados para a preservação da natureza, tinham uma relação circunstancialmente equilibrada com o meio em que viviam. Já os europeus eram partícipes de um sistema cultural que estabelecia uma cisão entre homem e natureza, praticamente opostos e mutuamente estranhos. Tinham também visões contraditórias destes povos indígenas, vivendo, segundo eles, em "estado de natureza", o que poderia indicar ou a sua barbárie incorrigível ou sua condição edênica, uma condição para a sua possível catequese e salvação. Além disso, estavam imbuídos de uma noção econômica que preconizava a acumulação de riquezas, especialmente minerais considerados preciosos, mediante a transformação da natureza em 
mercadoria. Natureza que no Maranhão reluzia com riquezas potenciais, dedicadamente descritas e ressaltadas no relato do capuchinho. Esta "zona de contato" representada pela França Equinocial significa a possibilidade da colonização do Maranhão pelos franceses, exaltando a opulência de seus recursos naturais e a "capacidade de aceitação da doutrina cristã manifestada pelos selvagens". ${ }^{1}$ Ou aquilo que Daher chama de "imperativo teológico da colonização francesa do Maranhão", ${ }^{2}$ a "dimensão providencial" deste território disputado aos portugueses cuja natureza edênica e paradisíaca, aliada à inocência do selvagem, confirma a sua vocação para a salvação por meio da obra missionária dos capuchinhos franceses.

Mais ainda, eram pessoas imersas num sistema religioso exclusivista, incapaz de tolerar a presença de outras expressões espirituais, uma mentalidade tão arraigada que dificultava a compreensão de tudo o que fosse diferente, condenando à destruição ou à marginalidade tudo que carregasse traços considerados idólatras ou pagãos. Por conta de tudo isso, o que resulta do processo não é uma simples substituição de um modo de vida por outro, mas, por vezes, a sobreposição da cultura europeia sobre a nativa, resultando num amálgama onde as práticas locais são ressignificadas e reorientadas para atender aos desígnios europeus. O viajante, para Doiron, é paradoxalmente um ser sedentário que despreza os nômades, os povos sem cidades, em nosso caso os ameríndios do Maranhão. "O deslocamento regrado dos viajantes modernos se definirá por oposição à vagabundagem dos selvagens que eles verão, com dois mil anos de intervalo, da mesma forma que Heródoto via os Citas". ${ }^{3}$ Ou seja, pelo espelho da diferença,

1 DAHER, Andréa. O Brasil francês. As singularidades da França Equinocial, 1612-1615. Trad. port. Alberto Stückenbruck. Rio de Janeiro: Civilização Brasileira, 2007, p. 103. Sobre a convertibilidade do selvagem, cf., da mesma autora, Do selvagem convertível. Topoi, Rio de Janeiro, v. 5, p. 71-107, 2002. E ainda A conversão dos Tupinambá entre oralidade e escrita nos relatos franceses dos séculos XVI e XVII. Horizontes Antropológicos, Porto Alegre, v. 10, n. 22, p. 67-92, jul./dez. 2004. Cf. ainda FISHMAN, Laura. Claude d'Abbeville and the Tupinambá: Problems and Goals of French Missionary Work in Early Seventeenth-Century Brazil. Church History, Cambridge University Press, v. 58, n. 1, p. 20-35, mar. 1989.

2 O Brasil francês, op. cit., p. 111 e s.

3 DOIRON, Normand. L'Art de Voyager. Le déplacement à l'époque classique. Sainte Foy: Les Presses de 1'Université Laval; Paris: Klincksieck, 1995, p. 7; cf. também p. 83. Cf. ROCHE, Daniel. Humeurs vagabondes. De la circulation des hommes et de l'utilité des voyages. Paris: Fayard, 2004, p. 62: "A viagem de Ulisses impregna todo pensamento clássico que rejeita a errância sem ordem e o nomadismo sem ponto fixo". Para as definições da viagem como fonte e como gênero, cf. TORRÃO Filho, Amilcar. $A$ arquitetura da alteridade: a cidade luso-brasileira na literatura de viagem (1783-1845). São Paulo: Hucitec/ Fapes, 2010. p. 15 e s. 
da oposição, da barbárie; não apenas os povos "selvagens", vivendo em estado de natureza, ou as culturas "decaídas" do oriente ou da África do norte, imersas em suas ruínas, mas também as civilizações "mestiças" da América, incapazes de recriarem no Novo Mundo uma cópia fiel de sua matriz europeia. No entanto, este espelho desvelado pela literatura dos sábios viajantes oferece "menos um material bruto que as representações e os julgamentos que ela compartilha". ${ }^{4}$ Este desconhecido, espelho da identidade do viajante, é projetado em imagens que oscilam entre o inferno e o paraíso, ora exemplo de organização utópica e perfeita, ora espaço da barbárie, que deve ser conquistada e civilizada. O longínquo se constitui nesta literatura "um espaço oximoro no qual a paisagem edênica dissimula às vezes um contrário insuportável". 5

Esta imagem especular que o viajante descobre fora de sua pátria, por mais cosmopolita que seja a atividade da viagem, é comparada por Doiron a um luto, não exatamente um sentimento de exílio, mas um sentimento "da incrível desordem que reina no mundo. Afastando-se do centro, ele descobre a ruptura". ${ }^{6}$ A esta imagem da desordem do mundo, o viajante opõe a sua ordem, a sua classificação: "À dispersão, ele responde pelo agrupamento, pela reunião dos signos que tornam inteligível o seu trajeto". ${ }^{7}$ Para este autor, a alteridade na literatura de viagem não é mais do que "uma monstruosa retórica do mesmo: comparação, analogia, metáfora, antítese, hipérbole". ${ }^{8}$ Esta operação de inteligibilidade do espaço é o que Gomez-Géraud chama de "ordenação do mundo, a partir do itinerário que faz desfilar os lugares", como sendo a principal preocupação do relato de viagem. ${ }^{9}$ Ainda aqui observamos o caráter contraditório da literatura de viagem: seus autores buscam a crítica de sua própria civilização na comparação com outras sociedades, tentando encontrar em sua "infância"

4 ROCHE, Daniel, op. cit., p. 215.

5 PIOFFET, Marie-Christine. Espaces lointains, espaces rêvés dans la fiction romanesque du Grand Siècle. Paris: Presses de 1'Université de Paris-Sorbonne, 2007. p. 34.

6 DOIRON, Normand, op. cit., p. 74.

7 Ibidem, p. 75.

8 De l'épreuve de l'espace au lieu du texte. Le récit de voyage comme genre. In: BEUGNOT, Bernard (Éd.). Voyages: récits et imaginaires. Actes de Montréal. Paris, Seattle, Tubingen: Wolfgang Leiner, 1984 , p. 24.

9 GOMEZ-GÉRAUD, Marie-Christine. Écrire le voyage au XVIe siècle en France. Paris: Presses Universitaires de France, 2000. p. 45. 
uma naturalidade e uma inocência que faltam à Europa polida, repleta de convenções e hierarquias, refletindo as ideias que Rousseau havia buscado em outros viajantes para desenvolver sua teoria do bom selvagem. Estes espaços, incluído o Brasil, constituem uma "renovação utópica" do pensamento europeu, da regeneração de sua cultura; "este sonho pacífico de uma América que seria o futuro da velha Europa corrompida e sangrenta". ${ }^{10}$

Além de renovação utópica para o pensamento europeu, para Certeau o encontro com o Novo Mundo provocou a invenção do selvagem na obra de Jean de Léry por meio de uma operação de escritura que ordena os fragmentos da oralidade indígena. Ou a constituição desta palavra instituída como lugar do outro e destinada a ser entendida outramente, de um modo diferente daquele que fala. Um espaço da diferença "que coloca em questão o funcionamento da palavra em nossas sociedades da escritura, e as relações entre história e etnologia". ${ }^{11}$ Certeau trata da formação desta voz que fala pelo indígena, deste discurso sobre o outro, perguntando-se qual é o ex-voto que "a escrita dirige à palavra ausente". ${ }^{2} \mathrm{O}$ relato de Léry permite $\mathrm{o}$ retorno de si mesmo a si mesmo pela mediação do outro. Algo escapa do texto: a palavra tupi, ela é do outro, não é recuperável, é um ato perecível que a escritura não pode relatar. A escrita percorre um caminho, vai do outro ao mesmo e do mesmo ao outro, construindo uma imagem identitária por meio desta busca de compreensão do outro. Entretanto, no "porta-joias do relato", diz ele, "a palavra selvagem faz o papel de joia ausente". ${ }^{13}$ Nesta hermenêutica do outro, ${ }^{14}$ na feliz expressão do autor, a oralidade do selvagem transformada em escritura e a natureza dão sentido ao processo de decifração do outro. A alteridade é o ponto de partida, é um aqui (nós) relativizado por um lá (eles) e uma linguagem sem substância. Converte-se em um lugar de verdade porque nele se produz o discurso que compreende um mundo. Para isso serve o selvagem: da afirmação de uma convicção se passa a uma convicção de saber. "Mas se, de início, a linguagem a restaurar era 'teológica', a que se estabelece de retorno é (em princípio) científica

10 MOUREAU, François. Paradojas brasileñas de las Luces francesas. In: LEAL Maria Luísa; FERNÁNDEZ, María Jesús; GARCÍA BENITO, Ana Belén (Coords.). Invitación al viaje. Mérida: Junta de Extremadura, 2006. p. 127.

11 CERTEAU, Michel de. L'écriture de l'histoire. Paris: Gallimard, 2002, p. 247.

12 Ibidem, p. 249.

13 Ibidem, p. 251.

14 Ibidem, p. 262. 
ou filosófica". ${ }^{15}$ A natureza é índice da diferença entre os mundos, ela dá ordem à diferença estabelecendo, por meio das analogias e das comparações, uma imagem veraz do par-delà em relação a um par-deçà, constituindo-se como um "mundo de alteridade máxima". ${ }^{16}$ Um mundo que, como recorda Lestringant, será marcado pela "obstinação de um olhar constantemente aplicado à diversidade das coisas", às suas singularidades, como sugere o título do relato de André Thevet, suspeitando, diz o autor, de um "universal humano", ${ }^{17}$ ainda longe, portanto, de uma "pretensão de universalismo" de uma antropologia "fundamentalmente etnocêntrica", representada pelo programa da Sociedade dos Observadores do Homem de 1796. ${ }^{18}$

Utopia que, no caso da França Equinocial, refletia também um desejo colonial de conquista e uma esperança de salvação das almas selvagens pelo cristianismo. No entanto, seus textos devolvem muitas vezes não mais do que uma imagem idealizada de sua própria cultura, depurada pela pena moralizante e utópica do viajante e sua memória livresca. Um olhar, que apesar de consciente da alteridade, faz da diferença do outro uma tópica do discurso moralista ou polêmico do escritor, "não guardando de sua identidade mais do que elementos largamente estereotipados". ${ }^{19}$ Cabe ressaltar o que é observado por Pioffet, com relação ao romance do Grand Siècle, e sua relação com a literatura de viagem: o exotismo - neste caso, o chinês - é ditado muito mais por "imperativos históricos que geográficos". A China apresentada pelos romances, "lugar espantosamente vazio, parece provir de uma convenção retórica sem referente extratextual". ${ }^{20}$ Mas, muitas vezes, as projeções da América portuguesa lembram o espaço vazio, a página em branco chinesa da literatura do Grand Siècle francês. "O vazio da carta se apresenta ao viajante como uma página em branco a ser escrita"; 21 a página em branco não é, aqui, apenas metáfora ou posição

15 Ibidem, p. 266.

16 Idem.

17 LESTRINGANT, Frank. A oficina do cosmógrafo, ou a Imagem do mundo no Renascimento. Trad. Edmir Missio. Rio de Janeiro: Civilização Brasileira, 2009. p. 33.

18 Ibidem, p. 111.

19 GOMEZ-GÉRAUD, Marie-Christine, op. cit., p. 45.

20 PIOFFET, Marie-Christine, op. cit., p. 172.

21 SCHAEFFER, Alain. "Ce ne pas un livre que j’écris". Equipée de Victor Segalen: le récit de voyage en question. In: GOMEZ-GÉRAUD, Marie-Christine; ANTOINE, Philippe (Dirs.). Roman et récit de voyage. Paris: Presses de 1'Université de Paris-Sorbonne, 2001. p. 89. 
epistemológica, é também a página do livro de viagem na qual se escreve o relato da alteridade; onde se projeta a imagem da identidade do viajante, onde se cristalizam os estereótipos com a liberdade que a criação literária permite, aliada às suas obrigações retóricas e à necessidade do convencimento do leitor de que se trata de um relato fiel e verdadeiro. E também a alma inconstante do selvagem, esta que não por acaso será identificada à página vazia do livro no qual se poderia escrever o texto de sua salvação.

A fantasia e o gosto pelo maravilhoso eram parte da mentalidade dos navegantes, descobridores, conquistadores e colonizadores dos séculos XVI e XVII. O contato com as realidades do Novo Mundo excedia a capacidade interpretativa e desafiava os conhecimentos tradicionais dos europeus, confrontando-os com experiências tão intensas que muitas vezes vertiam em expressão sobrenatural. A visão de uma terra abundante em alimentos e água, segura e previsível, aparecendo a homens famintos, sedentos, amedrontados pela sombra da morte, da doença, do naufrágio, sem dúvida sugeria algo de extraterreno. Ainda mais quando se considera a incipiência dos conhecimentos técnicos e científicos e que se percebe que estas experiências vinham de encontro com uma arraigada tradição construída na Antiguidade, incorporada pelo Cristianismo, retrabalhada pela literatura medieval, tão corriqueira que se fazia presente nas mentes desde os mais simples iletrados aos mais respeitados sábios.

Fazem parte dessa tradição as ideias que permitem supor a existência de um Paraíso terreal, ainda que objeto de polêmicas quanto às suas conformações espaciais, tangibilidade e mesmo, em alguns círculos, de sua ocorrência fora da esfera metafórica ou alegórica. De fato, o que seriam indícios dessa terra bem-aventurada aparecem com grande frequência nos relatos dos primeiros europeus sobre a América. Holanda considera este esquema, de origem bíblica, o modelo pelo qual os conquistadores decifraram o Novo Mundo, a forma pela qual eles decodificaram o universo sensível que encontraram na América. O continente alimentou uma esperança de "uma salvação neste mundo", não o mundo terreno já conhecido, mas em "alguma de suas partes ainda ignota $\mathrm{e}$ - quem sabe? - poupada à maldição divina". ${ }^{22}$

22 HOLANDA, Sérgio Buarque de. Visão do Paraíso: os motivos edênicos no Descobrimento e Colonização do Brasil. São Paulo: Brasiliense/Publifolha, 2000. p. 182-183. 
Se observada de outro ângulo que não o dos descobridores, navegantes e colonizadores, essa insistência em buscar realizar no Novo Mundo ideias e cenários previamente construídos no universo mental europeu pode ser definida como uma atitude etnocêntrica, que acabou decretando a "negação do outro". Por conta dessa mentalidade autocentrada, os europeus eram incapazes de reconhecer a existência de estruturas humanas diferentes das que se acomodavam em seu campo de conhecimentos e isso os levava a não admitir como válidas as manifestações culturais dos nativos da América. Cristóvão Colombo, expoente máximo desse tipo de atitude, chegou a negar inclusive que os nativos tivessem um sistema linguístico, afirmando em carta aos reis espanhóis, ainda em 1492, que "se Deus assim o quiser, no momento da partida levarei seis deles a Vossas Altezas para que aprendam a falar". ${ }^{23}$

Essas considerações iniciais buscam apontar as contingências que aparecem quando se lida com os escritos dos colonizadores, navegantes e conquistadores europeus. São relatos marcados por uma atitude mental singular que incidia sobre as descrições que fizeram do Novo Mundo, levando-os a adotar certos posicionamentos em relação ao homem e à natureza americanos que levantam suspeitas sobre sua fidelidade e grau de acuidade. Pensando descrever o Novo Mundo, tais pessoas acabaram, isso sim, elaborando aprofundados painéis de sua própria cultura e mentalidade. Isso se agrava ainda mais porque os nativos americanos eram iletrados e sua versão da história desapareceu junto com suas culturas. ${ }^{24}$ Por fim, há ainda a constatação de que, em muitos casos, os povos americanos descritos nos relatos desses europeus já tinham experimentado contatos prévios com a cultura do Velho Mundo e que muitos comportamentos, crenças e ideias que são descritos como próprios de sua cultura são, na verdade, amálgamas culturais. O que se rotula como cultura nativa, em muitos casos, é na verdade uma cultura mameluca, fruto do contato do indígena com o europeu.

23 TODOROV, Tzvetan. A conquista da América. A questão do outro. São Paulo: Martins Fontes, 1993. TODOROV, 1993, p. 30.

24 FISHMAN, Laura. Crossing Gender Boundaries: Tupi and European Women in the Eyes of Claude d'Abbeville. French Colonial History, New York: City University of New York, v. 4, p. 81-98, 2003. 


\section{As aves de Fernando de Noronha}

Ainda antes de chegar ao Maranhão, a frota francesa teve um primeiro contato com terras brasileiras em Fernando de Noronha, a qual "descobriu" no dia 23 de junho. A Ilha não era desabitada: encontraram "um português e 17 ou 18 índios, homens mulheres e crianças, todos escravos e para aí exilados pelos moradores de Pernambuco". ${ }^{25}$ A descrição que o capuchinho faz da Ilha indica que o local já estava marcado por alterações provocadas pela intervenção humana, uma vez que abundavam espécies exógenas introduzidas para benefício das pessoas. Abbeville conta que encontraram ali “ $[\ldots .$.$] muitos melões, jerimus, batatas, ervilhas, favas e outros$ frutos excelentes, bem como grande quantidade de milho e de algodão, além de bois, cabras selvagens, galinhas comuns [...]”. É provável que as tais "cabras selvagens" fossem na verdade descendentes de animais trazidos por navegantes e que, sem predadores naturais na Ilha, se tornaram verdadeiras pragas, reproduzindo-se em grande número e tomando espaço de espécies nativas na disputa por recursos.

Mas o que realmente impressionou os franceses foi a quantidade e a variedade de aves encontradas em Fernando de Noronha e na Ilha do Fogo, vizinha daquela. De imediato, todas as espécies foram classificadas como "comestíveis" e algumas chegaram a ser consideradas verdadeiras iguarias. Esfaimados após uma travessia onde os escassos víveres apodreciam, encontraram a Ilha coberta de aves, uma "grande multidão de pássaros de espécies desconhecidas em nossa terra", com a vantagem de serem “[...] bons de comer e fáceis de caçar, pois não somente se deixavam matar no ar e nas árvores a varetadas, mas deixavam-se pegar em seus ninhos sem se mexerem" (p. 47-48). A mortandade foi alta entre essas aves, que haviam se adaptado a ambientes livres de humanos e por isso eram indefesas contra sua voracidade e curiosidade mórbida. Tal comportamento nunca foi plenamente compreendido pelos europeus, que viam nisso sinal de estupidez. Para Abbeville, a atitude ingênua desses animais só podia ser explicada

25 ABBEVILLE, Claude d'. História da Missão dos Padres Capuchinhos na Ilha do Maranhão e terras circunvizinhas. Trad. port. Sérgio Milliet, Belo Horizonte: Itatiaia, 1975. p. 49. As referências seguintes do trabalho de Claude d'Abbeville serão citadas no corpo do texto com o número de página entre parênteses. 
como instinto de proteção, pois as aves "punham seus ovos no capim ou mesmo na terra, donde não se retiravam nem a pontapés, com medo talvez de esmagarem os ovos" (p. 48, grifo nosso). De qualquer forma, os membros da expedição não estavam muito interessados em compreender o comportamento das aves, desde que pudessem se servir desse conveniente "recurso". O relato do capuchinho oferece um quantitativo da voracidade dos europeus, explicando que eles consumiam "[...] por dia mais de cem dúzias, sem que se verificasse a menor diferença na quantidade, sem que o número parecesse diminuir" (p. 48).

O historiador Warren Dean, referindo-se ao que seria "a primeira leva de invasores" a perturbar a Mata Atlântica - os primeiros grupos humanos a penetrar no território da América do Sul -, descreve-os como consumidores imprevidentes e abusivos que "[...] haviam chegado a um paraíso do caçador - suas presas eram tão numerosas que pareciam intermináveis e tão despreocupadas que era desnecessário aproximar-se delas em silêncio". ${ }^{26}$ Não só essas palavras parecem se encaixar ao episódio dos franceses em Fernando de Noronha, como também poderiam ser adaptadas para explicar os acontecimentos desencadeados pela chegada dos europeus à América em geral. Surpreendidos por homens que eram movidos por interesses desconhecidos e estranhos, por suas técnicas, suas espécies exógenas e por seu exército microbiológico para os quais não havia similiares locais, as formas de vida da América estavam tão indefesas quanto as aves de Fernando de Noronha.

Os europeus não precisaram se aproximar em silêncio, porque foram recebidos ora como deuses, ora como amigos e quase sempre encontraram caminho aberto para seus empreendimentos, o que deve ter feito com que pensassem que os nativos, tal como as aves, eram estúpidos. Aves e índios, na verdade, apenas não tinham consciência, ainda, das ideias dos recém-chegados. Mesmo os astecas, que concebiam um mundo cíclico e acreditavam poder prever os acontecimentos, não podiam conhecer o grau de violência e destruição que esses estranhos iriam desencadear.

26 DEAN, Warren. A ferro e fogo: a história e a destruição da Mata Atlântica brasileira. São Paulo: Companhia das Letras, 1996. p. 39. 


\section{Cidade e agricultura}

Para os europeus, cidade era sinônimo de civilização, opondo-se à natureza, que, em sua mentalidade, era identificada como "selvagem". Isso implicava o afastamento da natureza, na circunscrição de áreas urbanas livres de mata e outros elementos naturais. ${ }^{27}$ A natureza, dessa forma, torna-se apenas fonte de matérias-primas. Na verdade, essa separação entre civilização e natureza significa que havia uma cisão mais profunda em ação: o homem europeu havia desenvolvido a noção de que a natureza era algo externo e oposto a ele, mais do que isso, estava a seu serviço, tanto o mundo natural inanimado quanto os animais, desprovidos de qualquer dimensão espiritual. Isso instaurou, segundo Thomas, "um corte absoluto entre o homem e o restante da natureza, limpando dessa forma o terreno para o exercício ilimitado da dominação humana". ${ }^{28}$

A construção das estruturas de apoio à colonização foi a cristalização dessa mentalidade. Escolheram "uma bela praça, muito indicada para esse fim por se achar no alto de uma montanha e na ponta de um rochedo inacessível e mais elevado do que todos os outros" (p. 57), onde instalaram o forte, as residências dos principais e vinte canhões. A vocação bélica do empreendimento transparecia nesse ato, que preparava o centro de poder para tornar-se capaz de impor e defender suas posições. Ali, com a ajuda dos índios, que "reconheceram a necessidade desse forte", edificaram também "[...] várias cabanas [...] de um e dois andares, e mais um grande armazém para o qual transportaram eles próprios [os índios] toda a carga dos nossos navios" (p. 58). Prossegue Abbeville dando uma utilidade prática à natureza:

Junto ao forte há uma grande praça tão cômoda quanto admirável. Nela se encontram belas fontes e regatos, que são a alma de uma cidade, existindo também todas as comodidades desejadas, como sejam paus, pedras, barro e outros materiais que tornam a construção barata (p. 58).

27 Cf. TORRÃO FILHO, Amilcar. A cidade como redenção: natureza e cultura nos Campos de Piratininga. In: MARTINEZ, Paulo Henrique (Org.). História ambiental paulista. Temas, fontes e métodos. São Paulo: Senac, 2007. p. 29-50.

28 THOMAS, Keith. O homem e o mundo natural: mudanças de atitude em relação às plantas e aos animais: 1500-1800. Trad. port. João Roberto Martins Filho. São Paulo: Companhia das Letras, 1988. p. 41. 
As espécies vivas tornam-se, assim, facilidades e conveniências para a vida humana. Aparece aí o plano geral dos franceses, que consistia em escolher o local pelas características geoambientais - um forte seguro, um espaço servido de água para a cidade - e o emprego dos índios como serviçais. Todo um modo de vida era transplantado para a área, num processo de "europeização" do espaço natural. Finalmente, Abbeville descreve a localização e a construção do convento que os abrigaria:

A mil ou mil e duzentos passos desse local, deparamos com um belo e aprazível lugar, onde existe uma fonte, particularmente bonita, de excelentes águas vivas e claras. Correm para o mar e é a fonte cercada de palmeiras, guacos, murtas e outras árvores maravilhosamente grandes e copadas, sobre as quais se veem muitas vezes monos, macacas e micos que vão beber água.

Nesse lugar delicioso, derrubaram os índios Tupinambás grande número de árvores e, um pouco acima da dita fonte, construíram uma cabana espaçosa e comprida para servir-nos de habitação, e outra ao lado para servir de capela e a celebração do santo sacrifício da missa. E deu-se a esse conjunto de construções o nome de Convento de São Francisco (p. 58).

Em contraste com a visão europeia da natureza e do lugar do homem em relação a ela estava a cultura nativa, que tinha outras condutas e práticas cotidianas. A “cidade" Tupinambá, por exemplo, aparece no relato de Abbeville pela via negativa, ou seja, em contraste com a cidade ideal do capuchinho:

[...] essas aldeias não são como as nossas, e menos ainda se parecem com cidades bem edificadas, cercadas de baluartes ou trincheiras, ou ainda de fossos, com ricos palácios, belas residências e castelos inexpugnáveis. Suas aldeias [...] não passam de quatro cabanas feitas de paus grossos ou estacas e cobertas de cima a baixo com folhas de palmeira [...] (p. 139).

Além disso, a itinerância das aldeias era também um comportamento estranho ao europeu, ainda que sobre ele Abbeville tenha evitado juízos, limitando-se a descrever o hábito: 
Após cinco ou seis anos, pois não costumam ficar mais tempo no mesmo lugar, destroem e queimam a aldeia e vão edificar outra mais adiante, a uma distância de meia légua pouco mais ou menos, dando-lhe, entretanto, o mesmo nome da precedente. Assim fazem, segundo afirmam, pela única razão de terem feito o mesmo seus antepassados (p. 222).

A colonização do Maranhão proposta pelos franceses era sedentária, ao contrário das aldeias dos Tupinambá. Isso implica o uso intensivo e prolongado dos recursos, que tendem ao esgotamento e à deterioração. Não que se advogue aqui a imagem surrada do "indígena puro", vivendo em perfeita harmonia com a natureza e com seus semelhantes. Tal estado de equilíbrio, apesar de ser difícil determinar com precisão, não parece ter ocorrido nunca, exceto circunstancialmente. Mas para a estratégia de conversão dos capuchinhos franceses, que reconhecem os Tupinambá como únicos proprietários destas terras, como recorda Daher, sua ocupação nômade faz com que se justifique também o fato de que "o direito de propriedade indígena também [seria] legitimamente transferível ao primeiro que plantasse a cruz", ${ }^{29}$ ou seja, ao primeiro que sedentarizasse os nômades da terra, por meio da cristianização, da agricultura e da vida em cidades. ${ }^{30}$

Warren Dean, preocupado em quantificar os estragos feitos à Mata Atlântica pelos humanos pré-europeus, conclui que as necessidades para manutenção provocam, invariavelmente, algum grau de desequilíbrio, independente de que grupo humano se trate. O que varia é o grau de perturbação causado. Os sambaquis, por exemplo, que são uma das primeiras culturas humanas a viver na região observada por esse historiador, recorriam menos à floresta porque seus recursos alimentares mais importantes vinham do mar, precisamente na forma de ostras. Ainda assim, percebe-se que o tamanho das ostras diminui a cada camada dos seus montes de concha e que há uma proporção crescente de restos de outros recursos alimentares. Tais evidências arqueológicas sinalizam que essas pessoas consumiram de forma excessiva os recursos, além da capacidade de reposição natural, recorrendo

29 DAHER, Andréa. O Brasil francês, op. cit., p. 125.

30 Cidade entendida aqui não apenas como uma forma urbana de ocupação do território, portanto sedentária, como também um princípio cristianizador pela Cidade Celeste agostiniana, como será discutido mais adiante. 
a espécimes cada vez mais jovens de ostras e, finalmente, a outras espécies em substituição a elas. Ou seja, estabeleceram uma relação insustentável e desequilibrada com o meio ambiente.

Se essa constatação é verdadeira para um grupo de coletores, o que dirá dos que praticavam a agricultura? Isso porque a agricultura é, em última instância, uma atividade que se desenvolve em áreas perturbadas. As espécies agrícolas úteis aos humanos são plantas que, sem intervenção, aparecem em apenas um momento específico, que é quando a queda das grandes árvores forma uma clareira, abrindo espaço para a penetração da luz solar. Nesse ambiente específico, fruto de uma perturbação, germinam plantas chamadas "precursoras", que são a etapa inicial da reconstituição da floresta. Dessa forma, para obter seus produtos agrícolas - que são gerados majoritariamente por plantas precursoras - os humanos precisam criar artificialmente esta perturbação, derrubando a floresta. Nas palavras de Dean:

Todos os regimes agrícolas representam transtorno a um ecossistema natural. Na verdade, procuram congelar a sucessão natural em seu estágio mais primitivo, introduzindo plantas cultivadas que, em seu estado selvagem, tinham sido espécies precursoras. $^{31}$

Essa tendência humana de obter seu sustento a partir da perturbação de regimes naturais é vista por Dean como sua vocação, o que coloca os humanos na categoria de "espécie invasora".

Dentro dessas considerações, entretanto, deve-se dizer em favor dos Tupinambá que seu regime agrícola, ainda que em última análise resultasse em algum grau de perturbação, era menos danoso que a agricultura intensiva. $\mathrm{O}$ estilo de agricultura indígena, itinerante, era "menos invasivo porque imita a escala natural de perturbação e, em vez de congelar permanentemente o processo de sucessão, apenas o explora de forma temporária". ${ }^{32} \mathrm{~A}$ agricultura itinerante praticada pelos Tupinambá do Maranhão foi descrita por Abbeville. Segundo ele, os indígenas justificavam seu nomadismo em função do respeito às tradições e também porque "[...] a mandioca e a batata 
com que se alimentam se comprazem em terras novas e produzem mais" (p. 222). O processo agrícola foi descrito pelo capuchinho:

Para fazer as roças cortam primeiramente o mato e deixam-no secar durante doze ou quinze dias; deitam-lhe fogo em seguida, de modo a reduzi-lo a cinzas. Limpo o lugar, plantam no centro muita mandioca para farinha; plantam também batatas, ervilhas, favas e semeiam outras ervas e raízes que lhes servem de alimento (p. 226).

As tarefas envolvidas na produção agrícola eram divididas entre os gêneros. Homens e adolescentes empregavam-se "[...] em cortar árvores e rotear a terra para as roças de mandioca" (p. 241), enquanto às mulheres era reservado o trabalho de cultivar, visto que "[...] depois de limpas as roças, e queimadas, compete-lhes fazer o resto". O trabalho, no entanto, não parece ao capuchinho ser muito pesado, pois consiste "[...] apenas em fincar o grão na terra dentro de buracos feitos com um pau" (p. 242). Essa pretensa facilidade se dava em função da fertilidade extrema da terra, característica que Abbeville atribui ao clima e à abundância de água:

[...] a terra é tão refrescada pelo sereno da noite e o orvalho da manhã, pelos rios e fontes e pelas chuvas da estação, que sem indústria nem cuidados basta semear a terra e cobri-la, sem sequer cavoucá-la antes, que dentro em pouco se tira bom resultado. [...] E pode-se verificar a bondade e admirável fertilidade dessa terra pelo fato de se poder semear e colher o milho com a mesma abundância três a quatro vezes por ano, donde incalculável lucro (p. 161).

Abbeville, decerto, desejava que a ideia de uma terra farta, que gerasse frutos "sem indústria nem cuidados", atraísse colonos para reforçar o empreendimento equinocial.

$\mathrm{Na}$ verdade, a fertilidade da terra se devia ao próprio ato de queimar a floresta. A queimada transforma os nutrientes da biomassa em cinzas que a chuva drena para a terra, fertilizando-a. ${ }^{33}$ Mas isso não se sustenta indefini- 
damente, pois com o tempo o solo se empobrece por falta de renovação de nutrientes, já que a agricultura os retira do solo quase sem oferecer reposição. Além disso, esse espaço perturbado artificialmente pelo homem acaba sendo invadido por ervas daninhas e pragas, entre as quais a mais danosa é a formiga cortadeira. Isso forçava os agricultores indígenas a abandonar a terra roteada e buscar novo local de plantio. Eles jamais voltavam a derrubar aquele trecho antes de um intervalo longo, que podia se estender de 20 a 40 anos; nesse período, a vegetação no local se reestabelecia, primeiro formando um grupo de arbustos e árvores pequenas, a chamada capoeira, e depois voltando a ser uma formação muito parecida com a original, com espécimes de grandes dimensões. Essa reconstituição reequilibrava a área, reduzindo as espécies invasoras a uma proporção normal.

Seria incorrer em anacronismo criticar a ignorância de Abbeville em relação a esses processos pedológicos que só bem mais tarde viriam a ser compreendidos pelos ocidentais. No entanto, os europeus não eram principiantes em matéria de manejo de solos. Estudos como o de Fernand Braudel, por exemplo, demonstram o quanto os tratos com a terra eram centrais em sua cultura, a ponto de influenciarem fortemente as organizações materiais, sociais e até psíquicas durante a Idade Média. Preocupados em manter uma produção regular de cereais, plantas responsáveis por fornecer a parte maior das calorias ingeridas, desde a Antiguidade os europeus desenvolveram dois sistemas de rotação, divididos grosso modo por região: ao Sul, os cereais ocupavam metade da área, enquanto que a outra metade descansava; no Norte, dividia-se a terra em três áreas, uma com o cereal de primavera, outra com o de inverno, e a terceira em repouso. ${ }^{34}$ Torna-se claro, portanto, que era praticamente impossível que um europeu desconhecesse a necessidade de descanso dos solos, mesmo que não compreendesse a fundo os mecanismos microscópicos que regiam esse sistema. A esses conhecimentos trazidos da Europa somaram-se na América aqueles obtidos pela observação dos hábitos dos índios, descritos afinal por Abbeville e por muitos outros missionários, colonos, conquistadores e cronistas do período dos primeiros contatos.

A roça de queimada, chamada também de coivara, acabou se tornando o modelo de exploração agrícola das terras no Brasil, sem que o 
respeito ao período de descanso fosse observado. Dean detectou esse modus operandi, pois ficaram registros dos inúmeros pedidos de novas sesmarias por fazendeiros que, depois de exaurir os solos de suas antigas possessões, seguiam em frente devastando novas terras. Keith Thomas nos recorda que neste momento a ideia de preservar a natureza, resistir à agricultura, teria parecido absurda aos europeus. Para o progresso da civilização, se consideravam imprescindíveis a limpeza das florestas, o cultivo do solo e a conversão da paisagem agreste em uma terra colonizada e modificada pelo homem. O homem havia sido criado por Deus para submeter a terra e os animais e plantas que viviam nela. Uma terra não cultivada era sinônimo de homens incultos, bárbaros, selvagens. Quando os ingleses se estabeleceram no século XVI em Massachusetts, na América do Norte, argumentaram em defesa da ocupação das terras dos índios que aqueles que por si mesmos não submetiam e cultivavam a terra não tinham direito de impedir que outros o fizessem. Até o século XVI, a visão tradicional era que o mundo fora criado para o beneficio do homem e as outras espécies deveriam se subordinar a seus desejos e necessidades. Qualquer teólogo ou intelectual, afirma Thomas, poderia usar a Bíblia e os filósofos antigos para justificar esse domínio. ${ }^{35}$

Essas reflexões questionam a ideia, antiga e persistente, de que os nativos possuíam um estilo de vida equilibrado e ecologicamente sustentável. A ação humana tende a ser sempre danosa, de forma que o equilíbrio somente existiria se houvesse alguma razão filosófica para se buscá-lo. Em outras palavras, os membros de tal grupo hipotético teriam que incorporar ao seu sistema de valores essenciais o da existência ecologicamente equilibrada, o que levaria à adoção de comportamentos específicos e interdições, limitando e direcionando as ações cotidianas. Não era esse o caso dos Tupinambá: nada havia em seu sistema de valores que indicasse uma preocupação com a preservação dos recursos, não havia entre eles um "pensamento ecológico" ou "preservacionista". Mesmo que no final eles desenvolvessem práticas menos invasivas, isso se dava por conveniência a suas necessidades, não por conta de preposições culturais. Dessa maneira, era um equilíbrio circunstancial e incerto, que poderia desaparecer a qualquer momento.

35 THOMAS, Keith, O homem e o mundo natural: mudanças de atitude em relação aos animais: 1500-1800. Trad. port. João Roberto Martins Filho. São Paulo: Companhia das Letras, 1988, p. 20 passim. 


\section{A eterna primavera}

O clima ameno do Maranhão, marcado pela constância, impressionou vivamente o capuchinho, que dedicou muitas páginas para louvar e explicar essa maravilha. Comparando-se essa característica brasileira com a inclemência dos invernos europeus, e juntando a isso a constatação de que aqui as árvores estavam sempre verdes, ele se aproxima do motivo edênico da "eterna primavera".

No inverno a terra é estéril na Europa, e no Brasil sempre fecunda; na Europa a terra é horrível no inverno, com a erva morta, as árvores desfolhadas, tudo seco. No Brasil é a verdura permanente, a terra está sempre adornada de belas plantas e de flores diversas e raras. Em suma, há no Brasil uma eterna primavera unida ao outono e ao verão. E uma tal suavidade de temperatura que em qualquer época do ano as árvores têm folhas, flores e frutos, os quais dão tal perfume à atmosfera, que os campos são croceis halantes floribus horti. Não estamos sujeitos na Europa, com as mudanças de estação, a toda espécie de doenças causadas pela inconstância e diversidade do clima? Pois no Brasil estamos sempre bem dispostos, porque temperie coeli corpusque, animus que juvatur. Vivem os homens longos anos. A própria terra, os animais, as águas e os peixes, o ar e os pássaros, as flores são diferentes dos de França em virtude do clima temperado da região. (p. 154).

Habilmente, Abbeville emprega essa propalada amenidade e salubridade da América para convencer mais franceses a emigrarem para essa terra bem-aventurada, engrossando o número de colonos e garantindo a solidez do empreendimento. Indica claramente as possibilidades de uso dos elementos locais, acenando inclusive com o potencial emprego dos nativos como mão de obra:

Não carece o país, por outro lado, de facilidades para a construção, pois além das belas madeiras tem pedras próprias para obras. Pode fabricar-se bom tijolo e não há falta de terras, areias e outras matérias-primas necessárias a uma boa argamassa e a um bom cimento. Nem faltam tampouco trabalhadores. (p. 163). 
E dirige suas prédicas especialmente aos trabalhadores especializados, que poderiam ajudar aos capuchinhos na obra de construção da cidade celeste encarnada nas terras maranhenses, como se pode perceber neste trecho:

\begin{abstract}
Mas se os negociantes, artistas e operários conhecessem a bondade e as vantagens desse país, garanto que não descansariam enquanto lá não fossem. E compreenderiam então que viveram sempre como o rato de Esopo, que se julgava feliz, embora cheio de necessidades, simplesmente porque mudara de lugar. Quantos não há entre nós que se esgotam no trabalho, dia e noite, e mal conseguem dar conta de seus encargos, chegando, no fim, à mísera condição de mendigar o pão para o próprio sustento e o de seus filhos? Se vivessem nesse país poderiam passar bem sem esforços, graças à facilidade da pesca e da caça aos pássaros e outros animais, aí abundantes; e com bem pouco trabalho e indústria seriam ricos em pouco tempo e lamentariam tão somente ter vivido tanto tempo em sua primitiva condição. (p. 163).
\end{abstract}

\begin{abstract}
Abbeville aponta, dessa forma, as condições de vida na Europa de seu tempo, em que a miséria rondava a todos. Note-se como a esta condição contrasta a noção edênica da América, habilmente manobrada pelo capuchinho em seu esforço de valorizar a empresa, numa singular simbiose de interesses práticos com a mentalidade fantástica típica daquele período de expansão territorial dos europeus.
\end{abstract}

\title{
Comércio e mercantilização
}

Aos poucos, e principalmente nos registros dos ocorridos após a chegada ao Maranhão, e ainda mais nas cartas trocadas do Novo ao Velho Mundo entre franceses separados pelo mar oceano, aparece a motivação maior do empreendimento francês: a busca de lucros com o comércio de mercadorias raras. Dessa forma, a descrição da natureza torna-se um balanço comercial e a curiosidade com o exótico - e mesmo a visão das maravilhas 
sobrenaturais - convive no relato com um pragmático levantamento das possibilidades econômicas. O sentido dessa mercantilização deve ser visto aqui tal como o que ocorreu na Inglaterra, um século e meio mais tarde, ${ }^{36}$ ou seja, um movimento em que as forças do mercado tomam controle do processo econômico, submetendo todas as outras esferas da vida humana a suas leis. Ainda que na Europa esse processo tenha sido obstaculizado por convenções tradicionais, dispositivos jurídicos e resistência social, na América ele procurou se impor desde o início, ainda que em Abbeville possamos ver a valorização de aspectos da cultura indígena, como a sua falta de usura. Nenhuma convenção social foi respeitada e o limite à destruição foi interposto apenas por insuficiências técnicas. Os missionários em geral, e capuchinhos em particular, condenavam a cobiça e o desdém demonstrados pelos colonos seus conterrâneos, mas, de maneira geral, transigiam parcialmente com esses males; mais tarde, grupos religiosos iriam constituir-se em focos de resistência à escravização dos índios, tornando-se incômodos aos avanços da exploração da terra utilizando o trabalho indígena. O desapego europeu ao Novo Mundo e seus habitantes era patente, comportamento anotado por Manuel da Nóbrega, que afirmou que "[...] de quantos lá vieram, nenhum tem amor a esta terra [...] porque todos querem fazer em seu proveito, ainda que seja à custa da terra, porque esperam de se ir". ${ }^{37}$

Não é de se espantar que fosse essa a natureza do empreendimento, pois que os franceses já comerciavam com os nativos do Maranhão há muito tempo. Em diversos pontos do relato apreende-se que os contatos comerciais entre eles já vinham de trinta ou quarenta anos. Os produtos então explorados eram o "[...] pau-brasil, madeiras preciosas e outras [...] o algodão, o urucu, espécie de tinta vermelha muito abundante e também outra tinta encarnada que se assemelha à laca", além de "canafístula [...] e ainda o bálsamo verdadeiro como na Arábia” (p. 162).

Esperava-se ainda introduzir ali novas culturas, ou ao menos dar ênfase àquelas que fossem mais lucrativas ao comércio. $\mathrm{O}$ capuchinho Arsênio de Paris, companheiro de Abbeville nessa missão, comenta em carta a um colega religioso da França, reproduzida na obra deste, que a produção de tabaco poderia ser comercialmente atrativa, uma vez que os

36 POLANYI, Karl. A grande transformação. Rio de Janeiro: Campus, 1977. p. 36.

37 DEAN, Warren, op. cit., p. 74. 
espanhóis haviam abandonado o cultivo desse produto em Trindade e havia demanda pela planta. Sugere ainda que enviem de França "boas sementes, bem guardadas em garrafas bem tapadas" (p. 294). Membros de ordens religiosas, como se sabe, eram conhecidos como zelosos hortelãos e foram responsáveis pela introdução de um sem-número de plantas exógenas na América. ${ }^{38}$

Em virtude dessa orientação comercial, a descrição de Abbeville apresenta sempre a tendência de enumerar as riquezas da terra, quantificando lucros potenciais. A própria expedição, segundo ele, sustentou-se na certeza de que ali havia "imensas riquezas, suscetíveis de serem transportadas para a França" (p. 22). Claude descreve a terra não como naturalista, mas com um olhar mercantil, transformando a natureza em cifras, calculando o valor de mercado das espécies nativas. Ao descrever animais, indica suas possibilidades de uso, seja como tração, como alimento ou ainda por suas peles "belas e preciosas". Ao tratar das árvores, afirma que como são de muitas espécies diferentes, ele irá se esquivar de descrever o que considera "árvores estéreis", para se ocupar das frutíferas e daquelas que oferecem algum tipo de uso prático - e potencialmente comercial - para as pessoas (p. 167).

Essa forma de se relacionar com a natureza era bastante estranha aos indígenas. É célebre o diálogo entre o índio e Jean de Léry sobre esse tema. O impulso acumulativo era um comportamento bastante diferente daquele praticado pelos nativos, que viam a natureza como fonte inesgotável de recursos e não se ocupavam de procurar obter nada além do necessário à sobrevivência imediata. A mentalidade mercantilista era tão incompreensível para os Tupinambá que provocava situações vistas como cômicas pelos franceses. Na volta à França, seis Tupinambá foram levados e, no primeiro contato com a Europa, na Inglaterra, espantaram-se com o fato de que somente através do dinheiro se podia obter o necessário à sobrevivência. Por considerarem pouco civilizada essa conduta, logo apelidaram os europeus de tapuitins, "bárbaros brancos". Ancorados em Falmouth, esperando bom tempo para seguir para a França, aconteceu de subirem a bordo pescadores trazendo ostras e peixes, que desejavam vender aos tripulantes. O que aconteceu em seguida divertiu os franceses: 
[...] vendo os índios que os franceses davam dinheiro aos pescadores em troca de suas ostras, que somente assim as podiam obter, teve um deles a sorte de encontrar uma medalha escura. Veio mostrá-la muito alegre perguntando quantas ostras poderia obter em troca. Sendo-lhe respondido que não sendo a peça de metal amarelo ou branco e nada valendo, os tapuitins zombariam dele se a apresentasse, tomou o índio imediatamente de um pedaço de giz, pintou de branco a medalha e deu-a a um dos pescadores pedindo-lhe ostras. O pescador pegou a medalha, olhou-a e pôs-se a rir como nós mesmos; mas, compreendendo a simplicidade do índio, deu-lhe algumas, mais para presenteá-lo do que pelo valor da peça. Mostrou-se o índio muito contente, mas não pôde deixar de comentar: 'Os tapuitins são muito avaros e não prestam para nada, pois só me deram ostras em troca de dinheiro"” (p. 236).

Abbeville compreendia que este comportamento não se devia à ingenuidade dos americanos, mas a seus costumes originais, que não previam esse tipo de relação econômica:

Não sabem, pois, os índios o que seja comprar e vender no intuito de juntar dinheiro, ouro ou prata, cujo valor desconhecem. Quando vendem seus escravos ou outros gêneros, o que costumam fazer com os franceses, que negociam com eles, fazem-no em troca de outras mercadorias que lhes agradam e dão a essa operação o nome de ajepuig, receber troco (p. 236).

Essa atitude, afinal, não é mal vista pelo capuchinho. Pelo contrário, Abbeville reverbera certo ressentimento com a busca ao lucro que remete às posições da Igreja em relação ao que considera usura. Para ele, a cobiça é motivo da ruína e da infelicidade dos homens, pois os índios, por prescindir de tais valores,

[...] vivem alegres e satisfeitos, sem pensar em trabalho. Quando não estão em guerra passam boa parte do dia no ócio, empregando o resto na dança, na cauinagem, na caça e na pesca, mais para alimentar-se e distrair-se que para juntar riquezas (p. 236). 
Percebe-se, portanto, que ainda que se dedique ao minucioso trabalho de apontar os potenciais produtos comerciais encontrados no Maranhão, Claude d'Abbeville parece, afinal, desgostoso com o que considera manifestações de cobiça nos franceses. Para ele, a sede de riquezas dos europeus, em contraste com a despreocupação dos nativos com essa sanha acumulativa, era a causa das desgraças daqueles e da vida feliz destes. A cobiça dos europeus os sujeita a "extremos esforços", "grandes preocupações", ao "trabalho de correr através de desertos e mares, entre os rochedos dos azares, para se enriquecer com tesouros alheios" (p. 235). "Os índios, ao contrário, vivem felizes sem cuidado, sem preocupar-se com os bens temporais", porque não dão "tratos à imaginação para amontoar ouro ou prata" (p. 235). Estão dessa forma afastados das "trapaças e de fraudes, de roubos e de furtos, tão comuns no comércio" (p. 235). Abbeville ajuda a fomentar com seus relatos cheios de sugestões comerciais a cobiça que ele mesmo condena, mas talvez o faça para conseguir atingir seu objetivo maior, que é assegurar a continuidade do empreendimento, único caminho de alcançar a sua riqueza particular, que são "os índios e selvagens Tupinambás, esses tesouros e pedras preciosas que procuramos através de tão longa viagem e através de tantos perigos" (p. 55). Afinal, riquezas terrenas e espirituais nem sempre estavam tão claramente delimitadas no pensamento do período, já que, como registrou Sérgio Buarque de Holanda, os esforços dos conquistadores se revestiam daquela "[...] mescla de espiritualidade e riqueza, de devoção e ambição, da religião do Cristo e do culto ao bezerro de ouro" ${ }^{39}$

Temporal e espiritual estavam essencialmente ligados; a missão catequizadora estava suspensa até que se tivesse a certeza do sucesso do empreendimento colonial. Yves d'Évreux, capuchinho que liderava o grupo de Abbeville, comentou em carta ao Provincial de Paris estas preocupações. Justifica a exiguidade de batismos, afirmando que ela não decorria da falta de interesse dos nativos; pelo contrário, se fora pelos seus pedidos insistentes, já poderiam ter batizado "cem mil deles". No entanto, os batismos estavam suspensos até que soubessem se sua Majestade realmente desejava "continuar esta colônia pelo lado temporal" (p. 292), sem o qual a missão perde sua capacidade de prosseguir. Evitam o batismo, portanto, temendo a apostasia. 
Mesmo que se pondere que nessas reflexões do capuchinho entram muitos dos preconceitos da época, é inegável que se testemunha aqui uma transição entre formas diferentes de lidar com o meio natural. Ainda que, conforme discutido anteriormente, os modos de vida dos Tupinambá nunca tenham sido sustentáveis, eles acabaram sendo substituídos por práticas muito mais danosas e destrutivas. Os próprios Tupinambá, afinal, acabariam cedendo às pressões e adotando novos padrões de existência, calcados nos valores europeus. O contato com os europeus já havia provocado mudanças sensíveis nos comportamentos dos nativos, detectadas e registradas por Abbeville, que relata ter ouvido de franceses que

[...] com eles viveram durante dezoito e vinte anos que no passado eram muito mais liberais. O pouco que receberam dos franceses em troca do muito que deram tornou-os finalmente avaros e desconfiados. E hoje nada fazem, nem dão, sem antes ter recebido muito mais. Ainda assim é bem pouco o que desejam em troca do que dão ou fazem (p. 228).

Junto desses novos valores, que vão se introduzindo lentamente entre os Tupinambá, seguem outros elementos novos que vão se aderindo a sua vida cotidiana, tornando-se indispensáveis. A posse de objetos de metal representou uma enorme transformação na vida dos nativos, como eles mesmos parecem reconhecer ao qualificar a vida antes deles como "miserável". Tais ferramentas, sem dúvida, acirraram sua capacidade de intervenção na natureza. Além disso, espécies animais trazidas pelos franceses já eram de uso comum. Um velho índio moribundo tenta convencer os capuchinhos a batizarem-no antes de sua morte, oferecendo "todas as galinhas que possuía em seu galinheiro" como estímulo ao ato (p. 110). Bovinos, vivendo em estado selvagem, receberam dos Tupinambá o nome de tapirê, o mesmo dado à anta. Os cães trazidos pelos europeus tiveram menos sorte. Atacados pelo terrível tung $a$ - verme também conhecido como bicho-de-pé - ficavam de tal maneira infestados que tinham que ser mantidos em redes.

Nessa primeira fase de contato entre as culturas, percebe-se um intercâmbio de espécies e práticas ocorrendo pacificamente, de forma a permitir aos indígenas atuar na seleção e na adaptação dos novos elementos ao seu modo de vida tradicional. Em pouco tempo, esse cenário deixaria de ser possível. A natureza era a região do mito, espaço não protegido, não or- 
ganizado, não construído, e a cidade era o recinto sagrado da civilização. Ao redor da cidade, uma zona de fronteira, o campo, era "habitada por seres cuja natureza parecia incerta e ambígua, entre o humano e o animal: a gente dos campos, que vivia segundo tradições antigas e se dedicava a técnicas arcaicas e quase rituais", muito distantes das formas civis, cultas e intelectuais da vida urbana ${ }^{40} \mathrm{Se}$, como recorda Certeau, a operação escritura do europeu fala pelo indígena, refazendo a experiência da oralidade por uma fala instituída como lugar do outro, o seu mundo nômade e a natureza que o circunda deverão ser paulatinamente substituídos pela vida civil e conversável das cidades, fossem elas as vilas e aldeamentos que procuravam sedentarizá-los, fossem as utopias que pretendiam edificar na América a Jerusalém Celeste como instrumento de conversão, ainda que obedeça à noção agostiniana de ser "peregrina": "Enquanto peregrina, a cidade celestial vai chamando cidadãos por todas as nações e formando, de todas as línguas, verdadeira cidade viajora". Esta cidade é celeste, ela representa não um espaço, mas a congregação dos homens que vivem segundo as leis de Deus. No entanto, ela não nega a cidade terrena, fundamental para congregar os homens em torno da palavra divina em oposição a uma natureza deletéria: "Em sua viagem a cidade celeste usa também da paz terrena e das coisas necessariamente relacionadas com a condição atual dos homens". A cidade terrena é um meio pelo qual se chegará à paz celeste, "verdadeira paz", quando "o corpo já não será animal [...] mas espiritual, sem necessidade alguma, plenamente submetido à alma". ${ }^{41}$ No contato com os índios, na apreciação edênica da natureza americana, a Jerusalém peregrina, representação da comunhão cristã e da conversão, será projetada pelos missionários nas terras americanas como um projeto a ser perseguido, uma utopia que pretendia tornar terrena a cidade celeste, tornar livre, ainda que fosse pela mais estrita sujeição, o gentio que habitava a América.

Recebido em junho de 2012. Aprovado em agosto de 2012.

40 ARGAN, Giulio Carlo. A história da arte como história da cidade. São Paulo: Martins Fontes, 1992, p. 213. Cf. THOMAS, Keith, op. cit., p. 290.

41 Santo Agostinho. A cidade de Deus (contra os pagãos). 2. ed. Petrópolis: Vozes; São Paulo: Federação Agostiniana Brasileira, 1990, parte II, p. 409. Cf. Santiago Quesada, La idea de ciudad en la cultura hispana de la Edad Moderna. Barcelona: Universitat de Barcelona, 1992, p. 46-47: "[...] o caráter evangelizador da Cidade de Deus agostiniana, a ideia de 'peregrinação', a superação das línguas e a conformação de uma 'sociedade viajora' parecem o traço básico dos missionários hispânicos”. É a mesma estratégia dos jesuítas no Brasil ou dos missionários franceses no Maranhão. 